\title{
NEW ZEALAND JOURNAL OF ECOLOGY
}

\section{Restoring mature-phase forest tree species through enrichment planting in New Zealand's lowland landscapes}

\author{
Adam S Forbes $^{1 *(D)}$, Kiri J Wallace ${ }^{2}$ (iD, Hannah L Buckley ${ }^{3}$, Brad S Case $^{3}$ iD, Bruce D Clarkson ${ }^{2}$ (D) \\ and David A Norton ${ }^{1}$ iD \\ ${ }^{1}$ Te Kura Ngahere | School of Forestry, University of Canterbury, New Zealand \\ ${ }^{2}$ Environmental Research Institute, University of Waikato, New Zealand \\ ${ }^{3}$ Te Kura Pūtaiao | School of Science, Auckland University of Technology, Auckland, New Zealand \\ *Author for correspondence (Email: adam@forbesecology.co.nz)
}

Published online: 7 February 2020

\begin{abstract}
New Zealand's formerly extensive lowland native forests have been comprehensively cleared or modified, and large areas of secondary-growth vegetation have subsequently established. These areas are comprised of native, exotic, and mixed tree and shrub species assemblages. The mature-phase canopy and emergent tree species representative of pre-human New Zealand forests are often rare or locally extinct in these forests, indicating negative ramifications for long-term biodiversity conservation and ecosystem service provision, especially such as carbon sequestration. The successful recruitment of mature-phase canopy and emergent tree species may be prevented by biotic and abiotic filters related to dispersal (e.g. lack of seed sources or lack of dispersal agents), environmental variation (e.g. unsuitable germination microclimate or light availability), and competition (e.g. exotic weed competition). Failure of mature-phase tree species to cross through these filters may halt forest succession and cause arrested development of the ecosystem. There are also social and cultural imperatives for restoring mature-phase tree species, such as reassembling desired forest habitat and landscapes and providing lost natural heritage and cultural resources. Therefore, to restore secondary forests, depauperate remnant forests and create new forests that have complex structure, high biomass, and natural canopy tree diversity, mature-phase canopy and emergent species should be reintroduced through human interventions (i.e. enrichment planting). Experiments demonstrate that mature-phase tree species establishment can be optimised through canopy manipulation to address competition for light. Such targeted management can determine successful recruitment of mature-phase tree species, as can weed maintenance post-enrichment planting and landscape-level pest animal control. Currently political focus is emphasising planting of new early-successional native forests. However, support from scientific research and policy development is essential to actively recruit mature-phase tree species where they are now poorly represented and hence forest succession may be arrested. Afforestation and emissions trading policies need to support the reinstatement of mature-phase tree species within existing regenerating and degraded forests and newly created forests to facilitate the substantial ecological and ecosystem service benefits they provide over the long-term.
\end{abstract}

Keywords: broadcast seeding, Emissions Trading Scheme, enrichment planting, forest canopy, forest restoration, mature-phase forest tree species, One Billion Trees, pre-human, restoration plantings, secondary forest

\section{Introduction}

Upon human arrival in New Zealand about 1230-1280 CE (Wilmshurst et al. 2008), lowland forests featured a diverse array of mature-phase forest tree species comprising a mix of native conifers (Podocarpaceae, Cupressaceae, Araucariaceae) and angiosperms, with the conifers often the structural dominants (Wardle 1991). These ancient forest assemblages evolved under the natural selection pressures of climate, physiography and disturbances (McGlone et al. 2001; Singers \& Rogers 2014; McGlone et al. 2016; Wyse et al. 2018;). Subsequent anthropogenic pressures such as large-scale deforestation (14 M ha, 71\% of original forest has been cleared; Ewers et al. 2006) have reshaped New Zealand's forests, resulting in starkly different composition, structure, and configuration of woody land-cover types. In particular, the original mature lowland forests have been extensively cleared, leaving small, ecologically isolated remnants that often lack large canopy and emergent tree species because they were selectively logged. Cieraad et al. (2015) have delineated and quantified the threatened environments of New Zealand-these are environments where indigenous cover is less than $10 \%$ of their former extent, thus being most threatened. This analysis provides a useful spatial framework for focusing on regions where active habitat restoration is required. Large-scale forest fragmentation typically creates impacts with long time lags, 
such as extinction debt of K-selected tree species (Vellend et al. 2006; Tilman et al. 1994). Large areas of secondary growth vegetation have established in some cleared areas, comprising completely native species, completely exotic, and sometimes mixed compositions. These secondary stands are often on fundamentally different successional trajectories to the forests of pre-human times (Sullivan et al. 2007).

Important in pre-settlement forests (Wardle 1991; McGlone et al.2017) were the conifers that occurred as canopy or emergent trees, including: (Podocarpaceae) Podocarpus totara (tōtara), Dacrycarpus dacrydioides (kahikatea), Prumnopitys taxifolia (mataī), and Dacrydium cupressinum (rimu), and in northern North Island, New Zealand, Agathis australis (Araucariaceae; kauri). Associated angiosperm canopy trees included: Beilschmiedia tawa (Lauraceae; tawa), Beilschmiedia tarairi (Lauraceae; taraire), Weinmannia racemosa (Cunoniaceae; kāmahi), Elaeocarpus dentatus (Elaeocarpaceae; hīnau), Dysoxylum spectabile (Meliaceae; kohekohe), Laurelia novae-zelandiae (Atherospermataceae; pukatea), Nestegis cunninghamii (Oleaceae; black maire), although Metrosideros robusta (Myrtaceae; northern rata) often grew as an emergent (Wardle 1991). The southern hemisphere beech (Nothofagaceae) species Fuscospora solandri (black beech), F. fusca (red beech), and F. truncata (hard beech) extended into lowland environments, although these species typically formed less species-rich forests (Wardle 1984).

Today, the mature-phase tree species that characterised New Zealand's pre-settlement forests are typically poorly represented, which may result in the functional or local extinction of these tree species. Intervention to establish these mature-phase tree species is paramount to ensuring representative, diverse, resilient, long-lived forest communities. Maintaining the presence of such trees is also important for restoring social practices such as use of taonga species (Harmsworth \& Awatere 2013) for whakairo (traditional Māori carving, e.g. P. totara; Timoti et al. 2017) and rongoā (medicine, Williams 2008; e.g. D. dacrydioides \& D. spectabile).

Currently, heavily deforested countries such as New Zealand promote biodiversity conservation through a focus on active planting of new forests where none exist, or facilitating natural regeneration (Norton et al. 2018). When forest cover is below $5-10 \%$, even small increases in cover may produce large benefits for native bird and other communities (Ruffell \& Didham 2017). This focus also helps to provide ecosystem services such as carbon sinks for climate change mitigation (Bastin et al. 2019; One Billion Trees Fund, Te Uru Rākau 2019). In addition to planting new forests, restoration through enrichment of existing degraded forest remnants is critical for meeting key conservation and ecosystem services objectives, including climate change mitigation. Support from scientific research and policy development could bolster restoration efforts to target the restoration of landscapes where mature-phase forest species are poorly represented or where ecological succession is arrested in an alternative stable ecosystem state (sensu Connell \& Slatyer 1977; Beisner et al. 2003). Such states require interventions to address filters limiting mature-phase tree species establishment such as seed dispersal (Kelly et al. 2010; Hansen \& Traveset 2012), exotic weed competition (Wallace et al. 2017), herbivory (Bernardi et al. 2019) and seed predation (Daniel 1973; Overdyck \& Clarkson 2012). It is likely that new forests planted from scratch under current government initiatives will face some of these barriers in the coming decades. We therefore suggest it is imperative that we enrich new forest restoration plantings, spontaneous natural regeneration, and depauperate forest remnants (of both native and exotic species). However, successful enrichment requires ecologically informed guidance and implementation and government policies and funding to enable long-term restoration goals.

Although restoring mature forest composition and structure is a long-term process (Crouzeilles et al. 2016), which comes with uncertain successional trajectories (Johnson \& Handel 2016), it is a highly desirable restoration aim to achieve a range of ecological, social and cultural benefits. To successfully establish mature-phase forest trees, it is critical we simultaneously appreciate the change in understory conditions during forest succession as well as the changing habitat requirements of mature-phase tree species as they age and develop. We can then appropriately target enrichment planting and management action timing.

As secondary forests develop sheltering canopies that provide stable microclimates and suppression of lightdemanding weeds, mature-phase tree species may germinate successfully (Wallace et al. 2017). The dominant canopy and emergent tree species typical of lowland forest remnants in New Zealand exhibit a range of variation in their light requirements, but generally seem to benefit from elevated light conditions associated with canopy gaps and similar disturbances (Knowles \& Beveridge 1982; Lusk \& Ogden 1992; Wyse et al. 2018). Therefore, as a forest matures into late succession, the initially planted early successional trees senesce, forming light gaps in which the saplings of maturephase tree species can grow towards the forest canopy. This process may only occur if the mature-phase tree species somehow colonise or are introduced to the forest (e.g. via dispersal agents or human intervention), otherwise a bare understorey may persist for many decades (Fig. 1).

In addition to challenges in appropriate environmental conditions and timing of the regeneration of mature-phase canopy and emergent tree species, common impediments to mature-phase tree seedling establishment and recruitment include reduced pollinator abundance, which can lead to reduced pollination and seed set (Rathcke \& Jules 1993), or local extinction of mature-phase species seed sources (Török et al. 2018; Fig. 2), or dispersal mechanism mutualisms (Kelly et al. 2010; Wotton \& Kelly 2011), any of which can cause dispersal failure. Even where seed successfully sets, and is successfully dispersed, favourable establishment sites can be unavailable due to disturbance regimes arising from land use (e.g. as might occur in landscapes containing high numbers of herbivores). Any one of these issues can prevent recruitment of mature-phase tree species.

To restore secondary and depauperate remnant forests with attributes such as complex vertical and horizontal structure, high biomass, and representative canopy diversity, maturephase canopy and emergent species will in many circumstances need to be reintroduced through human interventions such as planting seedlings and saplings (enrichment planting, also known as strip-, gap-, or under-planting) or direct seeding. There is, therefore, an urgent need to demonstrate the efficacy of interventions at management scales through experiments and to develop specific guidelines on incorporation of mature-phase tree species into existing native and exotic vegetation stands.

Here we review current practices for incorporating maturephase canopy and emergent tree species through enrichment planting generally and discuss the role of enrichment planting in forest restoration and permanent carbon forestry 


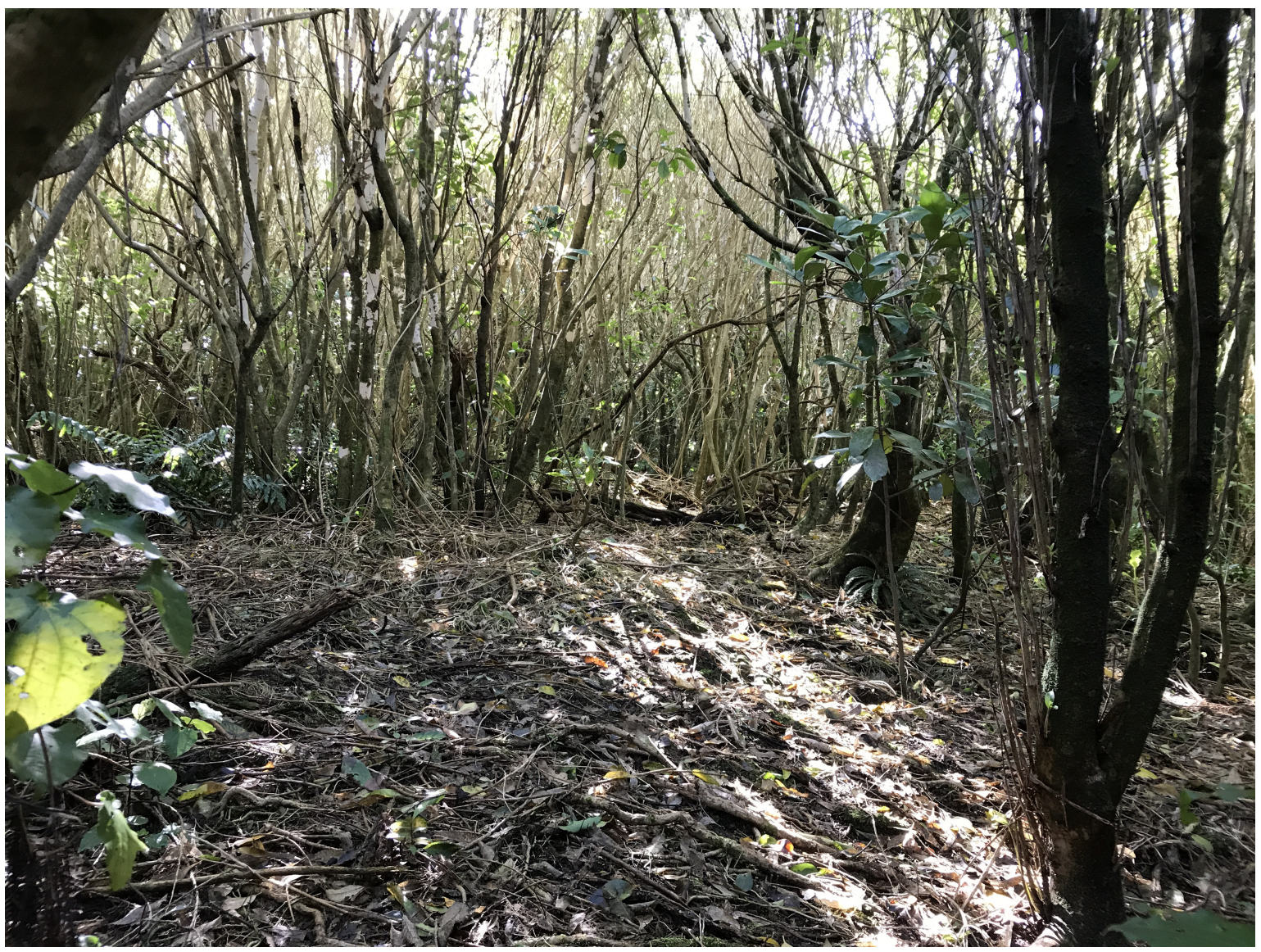

Figure 1. Heavily shaded understories of early-successional forests with full canopies, such as this Melicytus ramiflorus (māhoe) forest, may foster seedling establishment of mature-phase canopy species if they can reach the site. Later, canopy senescence and subsequent light gaps will be required for them to mature beyond the sapling stage and reach the canopy. Porirua, New Zealand (photo: AF).

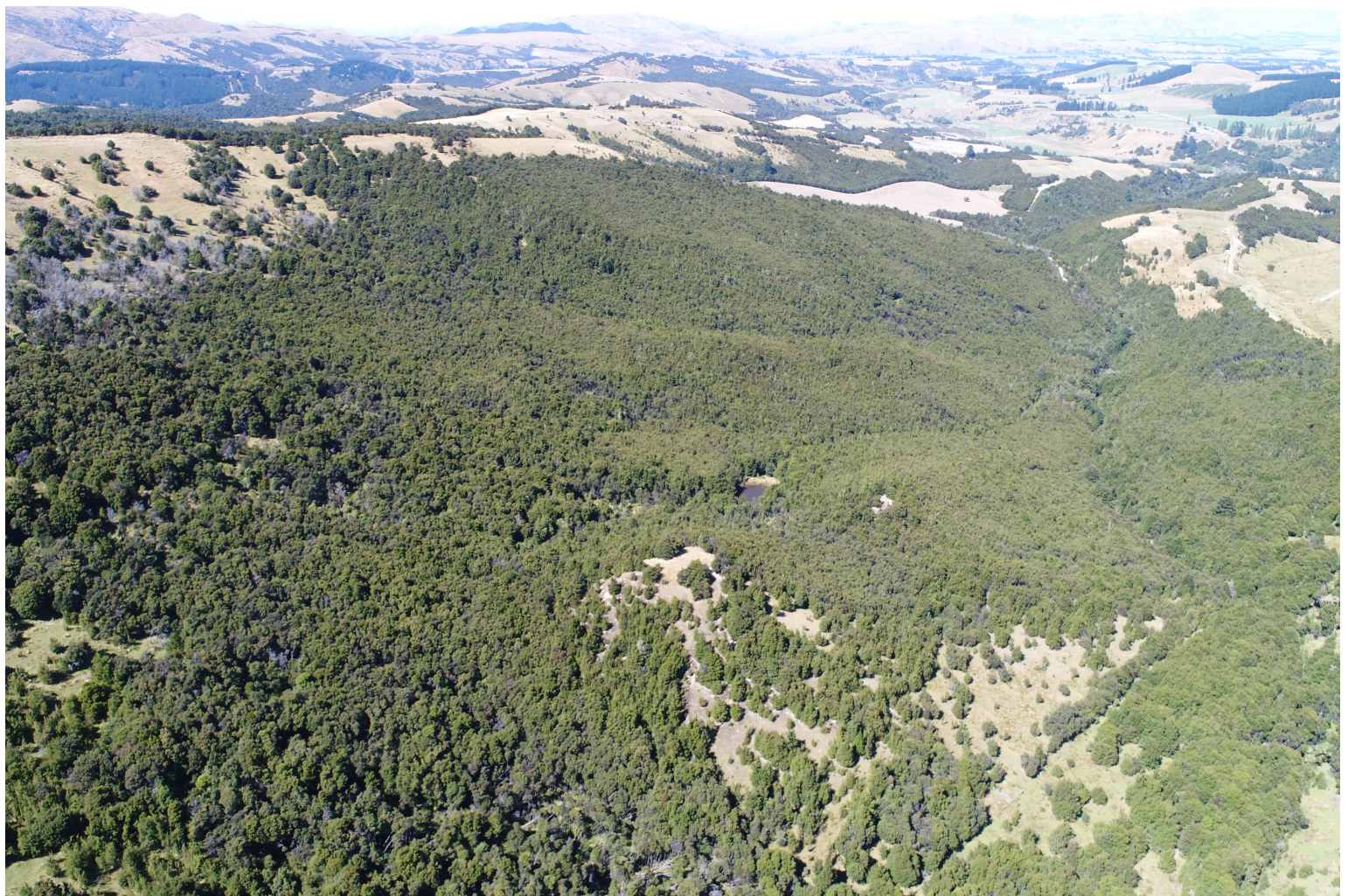

Figure 2. Large tracts of secondary Kunzea (Myrtaceae; kānuka) forest form persistent monocultures due to an absence of the mature-phase canopy or emergent tree species that would have characterised the mature forests. Near Waiau, Canterbury, New Zealand (photo: AF). 
in New Zealand. We also outline directions needed for future ecological research and policy support that will enable effective enrichment planting of mature-phase canopy and emergent tree species.

\section{Current practices and future research needs for restoring mature-phase tree species}

\section{Enrichment planting and mature-phase forest tree regeneration in canopy gaps}

Enrichment through planting and broadcast seeding to restore mature-phase tree species has been practiced globally (Ramos $\&$ del Amo 1992; Schulze 2008; Cole et al. 2011; Cunningham et al.2015; Bertacchi et al.2016). The performance of naturally established or human-introduced seedlings is typically assessed in contexts such as canopy gaps, cut lines, or beneath intact canopies. The structure of the vegetation surrounding the seedling is an index of available light and has been found universally to be the principal explanatory variable driving seedling growth (Paquette et al. 2006). In enrichment planting research, light environments have been quantified directly through surveys of percentage of available light (Magnoux et al. 2018), or indirectly through surveys of percentage of original stocking/biomass (Lu et al. 2018), percentage canopy cover or canopy openness (Gustafsson et al. 2016; Inada et al. 2017), or gap diameter to canopy height ratio (gap ratio, Zhu et al. 2019).

A global review (Paquette et al. 2006) of the survival and growth performance of canopy species beneath differing levels of forest cover concluded that growth followed a similar pattern in most biomes. In uncut stands, a sharp increase in seedling growth consistently resulted from canopy opening to create $<25 \%$ available light transmission, $>75 \%$ canopy cover, or a gap ratio of $<0.25$. In temperate biomes, further canopy opening to levels of $25-50 \%$ available light transmission, $50-75 \%$ canopy cover, or gap ratios of $0.25-0.4$, caused comparably more gradual increases in seedling growth, but beyond this level of canopy opening seedling growth tended to decline (Paquette et al. 2006). This review suggested that irrespective of biome, very open canopies (e.g. clear-cuts of c. $100 \%$ available light, c. $0 \%$ canopy cover, gap ratio $>2$ ) are not advantageous for growth or survival of mature-phase tree seedlings (Paquette et al. 2006). The performance of New Zealand's mature-phase tree species should be tested empirically in enrichment planting applications using universal indices such as these to allow international comparisons for growth and survival.

The importance of canopy gaps for passive regeneration of mature-phase tree species in remnant forest stands and in plantations is also well established in the existing literature (Runkle 1982; Kern et al. 2017). The performance of seedling regeneration in gaps varies with forest type, gap characteristics, average rainfall and temperature, seedling shade tolerance and soil nutrient availability (Coomes et al. 2009; Zhu et al. 2014; Lusk 2019). Some of these attributes have been tested experimentally in New Zealand's forest ecosystems, although it appears that no New Zealand studies have replicated the effect of gap treatments across gradients of rainfall and temperature, but see Ogden et al. (1991). Gap closure rates have not been assessed in New Zealand conditions, and we expect the effect of gap closure would be a function of canopy height (and vertical height growth rate) and the rate of horizontal growth that would eventually lead to gap closure. We expect that gap ratio would be a variable useful for quantifying levels of aboveground competition between enrichment planted seedlings and the surrounding vegetation cover across a diverse range of existing vegetation types.

\section{Recent New Zealand advances in enrichment planting}

Reconstructed forests (e.g. restored anew by planting) in the Waikato region have been used to assess the effect of early successional canopy age and composition on enrichment seedling survival, in particular, of shade-tolerant native angiosperms planted under canopies comprised primarily of Leptospermum scoparium (Myrtaceae; mānuka) and Kunzea spp. (Myrtaceae; kānuka) or other broadleaved native species (Laughlin \& Clarkson 2018). These reconstructed forests were initially planted at fairly high densities of up to 10000 stems $\mathrm{ha}^{-1}$ with no subsequent canopy manipulation to alter light conditions. High mortality (c. 70\%) of the enrichment species (i.e. the species planted through enrichment planting; Melicytus ramiflorus (Violaceae; māhoe), Litsea calicaris (Lauraceae; mangeao), Alectryon excelsus (Sapindaceae; tìtoki)) occurred under the older Leptospermum and Kunzea canopies and it was speculated that this could have been due to low light availability and possibly allelopathy (Laughlin \& Clarkson 2018). However, mortality of the same enrichment species was remarkably low (c. 30\%) under the planted broadleaved canopies of the same age, which differed by allowing more light to reach the forest floor. In a similar vein, twenty years after planting at the coastal restoration site Tiritiri Mātangi Island (north-east of Auckland), high-density (i.e. $85 \%$ canopy cover) restoration plantings of Metrosideros excelsa (Myrtaceae; pohutukawa) limited seedling abundance and richness compared with thinned $M$. excelsa stands or mixed species stands (both 56\% canopy cover; Forbes \& Craig 2013).

A study in north Canterbury trialled artificial canopy gaps as a means of addressing light limitation in mature Kunzea robusta (kānuka) forest to assist the growth and restoration of the long-lived native conifer P. totara (Tulod et al. 2019). Seedling height growth of $P$. totara was significantly greater beneath canopy gaps than under a closed canopy, with seedling growth rates in the gaps nearly twice those under the closed canopy. Gaps of approximately $3 \mathrm{~m}$ radius and 0.6 gap ratio allowed $33 \%$ of available light to reach the understorey (gaps where four Kunzea trees were removed). These canopy gaps equated to a $76 \%$ increase in transmitted light compared to that measured beneath the intact forest canopy (Tulod et al. 2019).

Canopy gap trials have also been used in conjunction with restoration of the mature-phase species $B$. tawa and P. totara in an 18 year old $24 \pm 0.5 \mathrm{~m}$ tall exotic Pinus radiata (Pinaceae; radiata pine) plantation in the eastern Marlborough Sounds (Forbes et al. 2016). Interspecific variation in life history traits was important for seedling growth and the species suitability between large (5.6 m radius; $84 \%$ light transmission; expanded gap ratio $=0.58)$ and small $(2.3$ $\mathrm{m}$ radius, $49 \%$ light transmission; expanded gap ratio $=$ $0.4)$ canopy gaps. The relatively light-demanding species $P$. totara grew better in large gaps while the shade-tolerant B. tawa grew better in small gaps. The effect of herbivory is an important secondary consideration of gap creation, with Forbes et al. (2016) recording greater levels of seedlings damaged from herbivore browse in large gaps. These results suggest a balance is require between canopy species palatability, shade tolerance, growth rate and gap size for successful restoration of mature-phase species within canopy gaps. 
In a large-scale forestry trial on the Kaingaroa Plateau (at $520 \mathrm{~m}$ above sea level) in the central North Island, three species of native conifer, D. dacrydioides, D. cupressinum, and P. totara were underplanted into a degraded Pinus ponderosa (Pinaceae; ponderosa pine) plantation of approximately 30\% Pinus canopy cover, with Pinus canopy cover gradually declining to approximately $5 \%$ at 51 years after underplanting (Forbes et al. 2015). Fifty-one years following planting, the best-performing native conifer, $D$. cupressinum, had attained $11.5 \pm 0.25 \mathrm{~m}$ height, $20.1 \pm 0.5 \mathrm{~cm}$ diameter at breast height, basal area of $16.5 \pm 2.1 \mathrm{~m}^{2} \mathrm{ha}^{-1}$, and had stored $32.3 \pm 3.9 \mathrm{t}$ $\mathrm{ha}^{-1}$ of carbon (Fig. 3; Forbes et al. 2015). In addition, Forbes et al. (2015) found that underplanting $D$. cupressinum resulted in a significantly higher native species richness in the forest understorey compared to the two other underplanted native conifer stands, indicating that an optimal species choice can result in good structural performance and the natural regeneration of shade-tolerant native plants.

In addition to light availability and seedling predation, limitation of enrichment plant establishment success has also been evaluated in the context of exotic weed competition. Research in Hamilton of urban forest remnant understoreys dominated by herbaceous weeds demonstrated that enrichment was most successful when planting tall $(>1 \mathrm{~m}) B$. tawa plants (Wallace 2017). Beilschmiedia tawa of this size typifies a mature-phase tree species seedling, exhibiting a slow growth rate, extreme shade-tolerance (Knowles \& Beveridge 1982; Carswell et al. 2012), and requirement for a stable understorey microclimate (Clarkson \& McQueen 2004). Despite the importance of a closed canopy to protect B. tawa from frosts and desiccation while young, growth rates increase for saplings if more indirect light is available from canopy gaps (Knowles \& Beveridge 1982), which also favourably warms the microclimate. In this work, an initial planting height of
$>1 \mathrm{~m}$ under a closed canopy limited suppression by the aggressive groundcover weed Tradescantia fluminensis (Commelinaceae; wandering Jew) (Standish et al. 2001). Beilschmiedia tawa growth rate was tested in conjunction with a factorial design including concurrent mulching and weeding, neither of which significantly increased growth rate over four years of establishment (Wallace 2017).

Broadcast seeding to introduce mature forest canopy species (E. dentatus; L. calicaris; B. tawa) was also trialled in Hamilton City urban forest restoration enrichment (Overdyck et al. 2013). This study determined to find best practice for limiting seed predation and improving seedling germination through a factorial design including a control and three factors: caging, removal of fleshy pericarp, and incorporation into fertiliser-enriched clay balls. Their results indicated that caging and clay balls significantly increased survival and establishment. Uncaged seeds were $58 \%$ predated compared with only $4 \%$ of caged seeds. Uncaged seeds with pericarp removal that were also in clay seed balls had a better outcome with an intermediate loss of $35 \%$. Use of the clay ball doubled the seedling establishment rates after germination in $B$. tawa $(6 \%$ vs $12 \%)$.

\section{Management interventions required to support enrichment planting}

Enriching existing vegetation with mature-phase canopy and emergent trees is likely to require supportive management by creating favourable planting sites, releasing (i.e. pruning or other forms of targeted vegetation removal) existing vegetation to address competition from surrounding vegetation, and also management at wider scales to address the effects of introduced herbivores and omnivores (Richardson et al. 2014).

Canopy gaps can be created through pruning, felling, ring barking (Tulod et al. 2019) or poisoning of existing

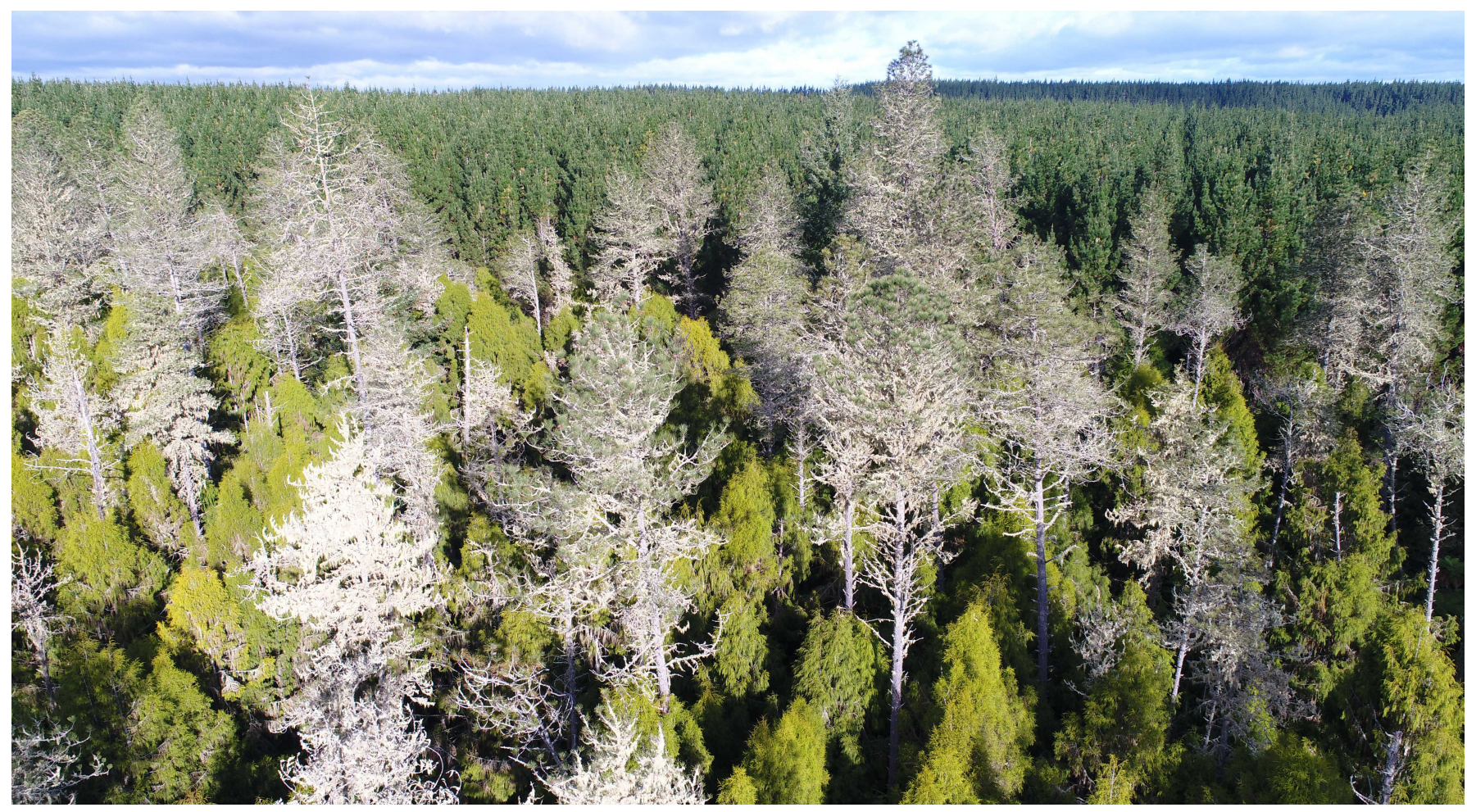

Figure 3. After 51 years, Dacrydium cupressinum (rimu) underplanted in a degraded Pinus ponderosa plantation has taken up structural dominance. Kaingaroa Plateau, central North Island, New Zealand. (photo: AF). 
canopy vegetation. The gap creation approach should be used conservatively in contexts subject to intense exotic seed rain because exotic species (e.g. herbaceous vines) may take advantage of the newly available light resources and outcompete the saplings of mature-phase tree species. Gap size can be controlled by the amount of vegetation manipulated and ongoing releasing (e.g. weed removal) may be necessary to minimise competition until the planted seedlings have grown into or above the surrounding canopy level (Paquette et al. 2006).

We suggest practical methods for helping to address the threat of herbivores and omnivores with large home ranges, such as Cervus elaphus (red deer), Capra hircus (feral goat) and Sus scrofa (pig), include establishing landscape-scale collaborations, such as community pest control schemes, and selecting mature-phase tree species of lower palatability (Forsyth et al. 2002). Furthermore, planting taller seedlings that will rapidly grow vertically out of the browse tier, and striking an appropriate balance of light-demanding life history traits and growth rates to ensure rapid growth even in the presence of browsers (Forbes et al. 2016). Another approach could be to plant mature-phase tree seedlings into situations featuring physical barriers to herbivores, thus reducing, or preferably avoiding, visitation by introduced mammals (Whyte \& Lusk 2019). Finally, government policies to remove herbivorous exotic mammals such as deer from public forests would help ensure the next generation of forest growth. Eradication of exotic mammalian herbivores and omnivores is the most desirable solution in the long term.

We see a need to explore novel opportunities to plant mature-phase tree species into the shelter of light-demanding exotic weeds, such as stands of the shrub Ulex europaeus (Fabaceae; gorse). This species forms dense monocultures and is less likely to be penetrated by introduced herbivores, thus providing safe sites for seedling growth. Methods that may be used to plant in such scenarios include the use of clay balls (Overdyck \& Clarkson 2012) and drone technology (Elliott 2016) for seed dispersal. Planting mature-phase tree species into communities dominated by light-demanding species reduces the threat of halted succession because the cover of light-demanding species will ultimately be suppressed and outcompeted through canopy shading by the planted species (e.g. Sullivan et al. 2007).

There are also potential risks arising from enrichment planting that need to be carefully managed. For instance, it is important that seedlings are ecosourced to avoid genetic homogenisation or the introduction of genetic material from maladapted local ecotypes, and the scrupulous nursery practices are enforced to prevent the propagation and spread of disease (Norton et al., 2018). Further, to ensure natural patterns in species distributions are correctly observed and maintained when enriching existing vegetation, species choice requires expert input.

\section{Enrichment planting in the context of restoration and climate change mitigation}

In contemporary fragmented landscapes, in particular those comprising predominately secondary regeneration or degraded urban forests, there are a number of situations where mature-phase canopy species will not join secondary forest successions or where they may only establish gradually over multiple centuries (Kelly et al. 2010; Rozendaal et al. 2019). Reduced recruitment of mature-phase canopy species limits the restoration of forest biodiversity and the ability of forests to sequester atmospheric carbon (Lennox et al. 2018). Mature-phase species are important for restoration of forest biodiversity as they provide unique ecological resources, habitats and structural features in forests (Lindenmayer 2017), while contributing long-term carbon sequestration and storage services (Luyssaert et al. 2008). Restoring mature-phase canopy and emergent species is, where required, an important restoration intervention to direct secondary successions for biodiversity restoration and climate change mitigation purposes. The draft National Policy Statement on Indigenous Biodiversity (NPSIB) (Biodiversity Collaborative Group 2018) recognises the need for creation of new indigenous dominated forests in biodiversity depleted environments of New Zealand, most notably urban and peri-urban zones. Proposed guideline 19 recommends restoration and reconstruction objectives for establishing a minimum of $10 \%$ indigenous cover in such environments.

We also see opportunities to reflect this important aspect of forest restoration in climate change policy. For instance, in New Zealand, the Emissions Trading Scheme (ETS; Climate Change Response Act 2002) classes forests that occurred prior to 1990 as not being eligible for registration under the ETS. Yet, in many cases, for the reasons given herein, natural forests in this class are incapable of recruiting mature-phase forest tree species and would require intervention to reintroduce ecologically valuable, long-lived, high-biomass canopy and emergent species to progress successional development. In this context, enrichment planting provides a means of addressing arrested successions in pre-1990 forests so that those stands can perform much-needed carbon sequestration and storage services. Similar benefits could be added to afforestation grants that do not currently support enrichment planting of existing forest stands (e.g. One Billion Trees Fund, Te Uru Rākau, 2019). In their current form, these schemes prevent opportunities to restore mature-phase canopy tree species and could be restructured to instead provide for the restoration of these species and the critical ecological and ecosystem services they provide. A current anomaly in the ETS also needs to be addressed where the definition of 'forest' regards pre-1990 native woody vegetation such as kānuka stands as ineligible for carbon credits, yet there are no carbon liabilities associated with converting them to plantation species. This policy can result in the perverse outcome of landowners clearing Kunzea stands that have the potential to develop into forests containing mature-phase canopy and emergent forest tree species. Better alignment of the One Billion Trees Fund and the NPSIB could also lead to better outcomes for both policy goals.

\section{Conclusions}

The canopy and emergent tree species that characterise New Zealand's lowland forest remnants are critical for supporting forest biodiversity and for ecosystem services such as atmospheric carbon sequestration and storage. Due to traits of mature-phase tree species and the limited establishment opportunities in contemporary landscapes, in many areas of New Zealand enrichment planting is required to ensure that these species join secondary successions in both native and exotic stands. Further work should be undertaken to determine where in New Zealand, for either social or ecological imperatives, enrichment planting or seeding is required. Managementscale experiments are required across rainfall and temperature gradients in order to develop clear restoration guidelines for 
planting into different statures and compositions of existing vegetation and to refine the requirements of establishment to ensure successful recruitment of planted mature-phase forest tree species. Additional research is also required to establish the optimum ways to include mature-phase canopy and emergent species in new native forest restoration plantings, and the potential role of exotic species such as pines and eucalypts as nurse species for their establishment. Climate change policy and governmental afforestation grants should recognise the importance of enrichment planting to enable the restoration of mature-phase forest tree species and the critical ecological and ecosystem services they provide. Anomalies, such as the ETS status of seral kānuka stands, should be removed. By investing in opportunities to enrich New Zealand's many forest types now, we will leave a valuable legacy for generations to come.

\section{Acknowledgements}

This work was partly funded by the Ministry of Business, Innovation and Employment (New Zealand's Biological Heritage NSC, C09X1501 \& UOW1601). The Ministry of Primary Industries-funded Kaikoura Post-Quake Farming Project provided considerable inspiration for the preparation of this paper. Two anonymous reviewers and Associate Editor Dr Sarah Wyse and Scientific Editor Professor George Perry provided helpful comments on an earlier version of this manuscript.

\section{References}

Bastin JF, Finegold Y, Garcia C, Mollicone D, Rezende M, Routh D, Zohner CM, Crowther TW 2019. The global tree restoration potential. Science 365(6448): 76-79.

Beisner BE, Haydon DT, Cuddington K 2003. Alternative stable states in ecology. Frontiers in Ecology and the Environment 1(7): 376-382.

Bernardi RE, Staal A, Xu C, Scheffer M, Holmgren M 2019. Livestock herbivory shapes fire regimes and vegetation structure across the global tropics. Ecosystems: 1-9.

Bertacchi MIF, Amazonas NT, Brancalion PHS, Brondani G, de Oliveir ACS, de Pascoa MAR, Rodrigue RR 2016. Establishment of tree seedlings in the understory of restoration plantations: Natural regeneration and enrichment plantings. Restoration Ecology 24(1): 100-108.

Biodiversity Collaborative Group 2018. Draft National Policy Statement on Indigenous Biodiversity. http://www. biodiversitynz.org/ (Accessed October 2019)

Carswell FE, Doherty JE, Allen RB, Brignall-Theyer ME, Richardson SJ, Wiser SK 2012. Quantification of the effects of aboveground and belowground competition on growth of seedlings in a conifer-angiosperm forest. Forest Ecology and Management 269: 188-196.

Cieraad E, Walker S, Price R, Barringer J 2015. An updated assessment of indigenous cover remaining and legal protection in New Zealand's land environments. New Zealand Journal of Ecology 39(2): 309-315.

Clarkson BD, McQueen JC 2004. Ecological restoration in Hamilton City, North Island, New Zealand. Presented at 16th International Conference, Society for Ecological Restoration. 24-26 August 2004, Victoria, Canada.
Climate Change Response Act 2002. http://www.legislation. govt.nz/act/public/2002/0040/latest/LMS152236.html (Accessed August 2019)

Cole RJ, Holl KD, Keene C, Zahawi RA 2011. Direct seeding of late-successional trees to restore tropical montane forest. Forest Ecology and Management 261(10): 1590-1597.

Connell JH, Slatyer RO 1977. Mechanisms of succession in natural communities and their role in community stability and organization. The American Naturalist 111(982): 1119-1144.

Coomes DA, Kunstler G, Canham CD, Wright E 2009. A greater range of shade-tolerance niches in nutrient-rich forests: An explanation for positive richness-productivity relationships? Journal of Ecology 97: 705-717.

Crouzeilles R, Curran M, Ferreira MS, Lindenmayer DB, Grelle CE, Benayas JMR 2016. A global meta-analysis on the ecological drivers of forest restoration success. Nature Communications 7: 11666.

Cunningham SC, Mac Nally R, Baker PJ, Cavagnaro TR, Beringer J, Thomson JR, Thompson RM 2015. Balancing the environmental benefits of reforestation in agricultural regions. Perspectives in Plant Ecology, Evolution and Systematics 17(4): 301-317.

Daniel M 1973. Seasonal diet of the ship rat (Rattus $r$. rattus) in lowland forest in New Zealand. Proceedings of the New Zealand Ecological Society 20: 21-30.

Elliott, S 2016. The potential for automating assisted natural regeneration of tropical forest ecosystems. Biotropica 48(6): 825-833.

Ewers RM, Kliskey AD, Walker S, Rutledge D, Harding JS, Didham RK 2006. Past and future trajectories of forest loss in New Zealand. Biological Conservation 133(3)312-325.

Forbes A, Craig J 2013. Assessing the role of revegetation in achieving restoration goals on Tiritiri Matangi Island. New Zealand Journal of Ecology 37(3): 343-352.

Forbes AS, Norton DA, Carswell FE 2015. Underplanting degraded exotic Pinus with indigenous conifers assists forest restoration. Ecological Management \& Restoration 16(1): 41-49.

Forbes AS, Norton DA, Carswell FE 2016. Tree fern competition reduces indigenous forest tree seedling growth within exotic Pinus radiata plantations. Forest Ecology and Management 359: 1-10.

Forsyth DM, Coomes DA, Nugent G, Hall GMJ 2002. Diet and diet preferences of introduced ungulates (Order: Artiodactyla) in New Zealand. New Zealand Journal of Zoology 29(4): 323-343.

Gustafsson M, Gustafsson L, Alloysius D, Falck J, Yap S, Karlsson A, Ilstedt U 2016. Life history traits predict the response to increased light among 33 tropical rainforest tree species. Forest Ecology and Management 362:20-28.

Hansen DM, Traveset A 2012. An overview and introduction to the special issue on seed dispersal on islands. Journal of Biogeography 39(11): 1935-1937.

Harmsworth GR, Awatere S 2013. Indigenous Māori knowledge and perspectives of ecosystems. In: Dymond $\mathrm{J}$ ed. Ecosystem services in New Zealand: Conditions and trends. Palmerston North, Manaaki Whenua Press. Pp. 274-286.

Inada T, Kitajima K, Hardiwinoto S, Kanzaki M 2017. The effect of logging and strip cutting on forest floor light condition and following change. Forests 8(11): 425.

Johnson LR, Handel SN 2016. Restoration treatments in urban park forests drive long-term changes in vegetation 
trajectories. Ecological Applications 26(3): 940-956.

Kelly D, Ladley JJ, Robertson AW, Anderson SH, Wotton DM, Wiser SK 2010. Mutualisms with the wreckage of an avifauna: The status of bird pollination and fruit-dispersal in New Zealand. New Zealand Journal of Ecology 34(1): 66-85.

Kern C, Burton JI, Raymond P, D'Amato AW, Keeton WS, Royo AA, Walters MB, Webster CR, Willis JL 2017. Challenges facing gap-based silviculture and possible solutions for mesic northern forests in North America. Forestry: An International Journal of Forest Research 90(1): 4-17.

Knowles B, Beveridge AE 1982. Biological flora of New Zealand 9. Beilschmiedia tawa (A. Cunn.) Benth. et Hook. F. ex Kirk (Lauraceae) Tawa. New Zealand Journal of Botany 20: 37-54.

Laughlin DC, Clarkson BD 2018. Tree seedling survival depends on canopy age, cover and initial composition: Trade-offs in forest restoration enrichment planting. Ecological Restoration 36(1): 52-61.

Lennox GD, Gardner TA, Thomson JR, Ferreira J, Berenguer E, Lees AC, Mac Nally R, Aragāo LE, Ferraz SF, Louzada J, Moura, NG 2018. Second rate or a second chance? Assessing biomass and biodiversity recovery in regenerating Amazonian forests. Global Change Biology 24(12): 5680-5694.

Lindenmayer DB 2017. Conserving large old trees as small natural features. Biological Conservation 211, 51-59.

Lu D, Wang GG, Zhang J, Fang Y, Zhu C, Zhu J 2018. Converting larch plantations to mixed stands: Effects of canopy treatment on the survival and growth of planted seedlings with contrasting shade tolerance. Forest Ecology and Management 409: 19-28.

Lusk CH 2019. Leaf functional trait variation in a humid temperate forest, and relationships with juvenile tree light requirements. PeerJ 7: e6855.

Lusk C, Ogden J 1992. Age structure and dynamics of a podocarp-broadleaf forest in Tongariro National Park, New Zealand. Journal of Ecology 80(3): 379-393.

Luyssaert S, Schulze ED, Börner A, Knohl A, Hessenmöller D, Law BE, Ciais P, Grace, J 2008. Old-growth forests as global carbon sinks. Nature 455(7210): 213.

Magnoux A, Cogliastro A, Paquette A2018. Growth of planted seedlings inside protective sleeves under strip openings of different widths in a post-agricultural forest. New Forests 49(2): 279-296.

McGlone MS, Duncan RP, Heenan PB 2001. Endemism, species selection and the origin and distribution of the vascular plant flora of New Zealand. Journal of Biogeography 28(2): 199-216.

McGlone MS, Buitenwerf R, Richardson SJ 2016. The formation of the oceanic temperate forests of New Zealand. New Zealand Journal of Botany 54(2): 128-155.

McGlone MS, Richardson SJ, Burge OR, Perry GLW, Wilmshurst JM 2017. Palynology and the ecology of the New Zealand Conifers. Frontiers in Earth Science 5: 94.

Norton DA, Butt J, Bergin DO 2018. Upscaling restoration of native biodiversity: ANew Zealand perspective. Ecological Management \& Restoration 19(S1): 26-35.

Ogden J, Fordham RA, Pilkington S, Serra RG 1991. Forest gap formation and closure along an altitudinal gradient in Tongariro National Park, New Zealand. Journal of Vegetation Science 2(2): 165-172.

Overdyck E, Clarkson BD 2012. Seed rain and soil seed banks limit native regeneration within urban forest restoration plantings in Hamilton City, New Zealand. New Zealand Journal of Ecology 36(2): 177-190.

Overdyck E, Clarkson BD, Laughlin DC, Gemmill CEC 2013. Testing broadcast seeding methods to restore urban forests in the presence of seed predators. Restoration Ecology 21(6): 763-769.

Paquette A, Bouchard A, Cogliastro A 2006. Survival and growth of under-planted trees: A meta-analysis across four biomes. Ecological Applications 16(4): 1575-1589.

Ramos J, del Amo, S 1992. Enrichment planting in a tropical secondary forest in Veracruz, Mexico. Forest Ecology and Management 54(1): 289-304.

Rathcke BJ, Jules ES 1993. Habitat fragmentation and plantpollinator interactions. Current Science 65(3): 273-277.

Richardson SJ, Holdaway RJ, Carswell FE 2014. Evidence for arrested successional processes after fire in the Waikare River catchment, Te Urewera. New Zealand Journal of Ecology 38(2): 221-229.

Rozendaal DM, Bongers F, Aide TM, Alvarez-Dávila E, Ascarrunz N, Balvanera P, Becknell JM, Bentos TV, Brancalion PHS, Cabral GAL, Calvo-Rodriguez S, Chave J, César RG, Chazdon RL, Condit R, Dallinga JS, de Almeida-Cortez JS, de Jong B, de Oliveira A, Denslow JS, Dent DH, DeWalt SJ, Dupuy JM, Durán SM, Dutrieux LP, Espírito-Santo M, Fandino MC, Fernandes GW, Finegan B, García H, Gonzalez N, Granda Moser V, Hall JS, Hernández-Stefanoni JL, Hubbell S, Jakovac C, Johanna Hernández A, Junqueira AB, Kennard D, Larpin D, Letcher SG, Licona J-C, Lebrija-Trejos E, Marín-Spiotta E, Martínez-Ramos M, Massoca PES, Meave JA, Mesquita RCG, Mora F, Müller SC, Muñoz R, Nolasco de Oliveira Neto S, Norden N, Nunes YRF, Ochoa-Gaona S, OrtizMalavassi E, Ostertag R, Peña-Claros M, Pérez-García EA, Piotto D, Powers JS, Aguilar-Cano J, RodriguezBuritica S, Rodríguez-Velázquez J, Romero-Romero MA, Ruíz J, Sanchez-Azofeifa A, Silva de Almeida A, Silver WL, Schwartz NB, Thomas WW, Toledo M, Uriarte M, Valadares de Sá Sampaio E, van Breugel M, van der Wal H, Venâncio Martins S, Veloso MDM, Vester HFM, Vicentini A, Vieira ICG, Villa P, Williamson GB, Zanini KJ, Zimmerman J, Poorter L 2019. Biodiversity recovery of neotropical secondary forests. Science Advances 5(3): eaau3114.

Ruffell J, Didham RK 2017. Conserving biodiversity in New Zealand's lowland landscapes: Does forest cover or pest control have a greater effect on native birds? New Zealand Journal of Ecology 41(1): 23-33.

Runkle JR 1982. Patterns of disturbance in some old-growth mesic forests of eastern North America. Ecology 63(5): $1533-1546$

Schulze M2008. Technical and financial analysis of enrichment planting in logging gaps as a potential component of forest management in the eastern Amazon. Forest Ecology and Management 255(3-4): 866-879.

Singers N, Rogers G 2014. A classification of New Zealand's terrestrial ecosystems. Science for Conservation 325. Wellington, Department of Conservation. $91 \mathrm{p}$.

Standish RJ, Robertson AW Williams PA 2001. The impact of an invasive weed Tradescantia fluminensis on native forest regeneration. Journal of Applied Ecology 38(6): $1253-1263$.

Sullivan JJ, Williams PA, Timmins SM 2007. Secondary forest succession differs through naturalised gorse and native kānuka near Wellington and Nelson. New Zealand Journal 
of Ecology 31(1): 22-38.

Te Uru Rākau 2019. https://www.mpi.govt.nz/fundingand-programmes/forestry/planting-one-billion-trees/ (Accessed August 2019).

Tilman D, May RM, Lehman CL, Nowak MA 1994. Habitat destruction and the extinction debt. Nature 371(6492): 65.

Timoti P, Jones CJ, Richardson SJ, Tahi BL, Greenhalgh S 2017. An indigenous community-based monitoring system for assessing forest health in New Zealand. Biodiversity and Conservation 26(13): 3183-3212.

Török P, Helm A, Kiehl K, Buisson E, Valkó O 2018. Beyond the species pool: Modification of species dispersal, establishment, and assembly by habitat restoration. Restoration Ecology 26: S65-S72.

Tulod AM, Norton DA, Sealey C 2019. Canopy manipulation as a tool for restoring mature forest conifers under an early-successional angiosperm canopy. Restoration Ecology 27(1): 31-37.

Vellend M, Verheyen K, Jacquemyn H, Kolb A, Van Calster H, Peterken G, Hermy M. 2006. Extinction debt of forest plants persists for more than a century following habitat fragmentation. Ecology 87(3): 542-548.

Wallace KJ 2017. Urban restoration ecology: Investigating environmental change, ecological function, and enrichment planting. Unpublished $\mathrm{PhD}$ thesis, University of Waikato, Hamilton, New Zealand.

Wallace KJ, Laughlin DC, Clarkson BD 2017. Exotic weeds and fluctuating microclimate can constrain native plant regeneration in urban forest restoration. Ecological Applications 27(4): 1268-1279.

Wardle JA 1984. The New Zealand beeches: Ecology utilisation and management. Wellington, New Zealand Forest Service. $447 \mathrm{p}$.

Wardle P 1991. Vegetation of New Zealand. Cambridge, Cambridge University Press. 672 p.

Whyte HD, Lusk CH 2019. Woody debris in treefall gaps shelters palatable plant species from deer browsing, in an old-growth temperate forest. Forest Ecology and Management (448): 198-207.

Williams PME 2008. Te Rongoa Maori medicine. Wellington, Raupo Publishing. $80 \mathrm{p}$.

Wilmshurst JM, Anderson AJ, Higham TGF, Worthy TH 2008. Dating the late prehistoric dispersal of Polynesians to New Zealand using the commensal Pacific rat. Proceedings of the National Academy of Sciences 105: 7676-7680.

Wotton DM, Kelly D 2011. Frugivore loss limits recruitment of large-seeded trees. Proceedings of the Royal Society B: Biological Sciences 278: 3345-3354.

Wyse SV, Wilmshurst JM, Burns BR, Perry GL 2018. New Zealand forest dynamics: Areview of past and present vegetation responses to disturbance, and development of conceptual forest models. New Zealand Journal of Ecology 42(2): 87-106.

Zhu C, Zhu J, Wang GG, Zheng X, Lu D, Ga T 2019. Dynamics of gaps and large openings in a secondary forest of Northeast China over 50 years. Annals of Forest Science 76(3): 72.

Zhu J, Lu D, Zhang W 2014. Effects of gaps on regeneration of woody plants: A meta-analysis. Journal of Forestry Research 25(3): 501-510.

Received 26 August 2019; accepted 18 November 2019

Editorial board member: Sarah Wyse 